\title{
Antimicrobial potential of Jurema preta and umburana, native species of the Caatinga biome, on Staphylococcus isolated from small ruminants with mastitis
}

\section{Potencial antimicrobiano de jurema preta e umburana, espécies nativas do bioma caatinga, frente a isolados de Staphylococcus provenientes de casos de mastite em pequenos ruminantes}

\author{
Maura Marinete de Sousa ${ }^{1}$; Renata de Moraes Peixoto Araújo ${ }^{2}$; Rafael Cunha \\ Libório $^{3}$; Eliatania Clementino Costa ${ }^{3}$; Beatriz Nascimento de Araujo ${ }^{4}$; Marcos \\ dos Santos Lima ${ }^{5}$; Gisele Veneroni Gouveia ${ }^{6}$; Mateus Matiuzzi da Costa ${ }^{6}$; Luciana \\ Jatobá e Silva Peixoto ${ }^{5}$; Rodolfo de Moraes Peixoto ${ }^{5 *}$
}

\section{Highlights:}

The flavonoid myricetin is found in high concentrations in extracts of C. leptophloeos.

Native plant extracts of the Caatinga biome demonstrate antibacterial activity.

The toxicity test suggests the absence of toxic potential in the natural extract of $C$. leptophloeos.

\begin{abstract}
Mastitis is responsible for both damage to animal health and economic losses to the industry. To identify effective treatments for this disease, products extracted from a variety of plants with antimicrobial potential have gained attention. The present study aimed to assess the in vitro antibacterial potential of the ethanolic extract of two plant species from the Caatinga biome against bacteria isolated from small ruminants with subclinical mastitis. The leaves of Mimosa tenuiflora and Commiphora leptophloeos were dried and processed to obtain crude ethanolic extracts and their phenolic composition was evaluated. In total, 33 Staphylococcus spp. isolates from the bacterial collection of the Laboratory of Food Quality Control of IF SERTÃO-PE were used for evaluation of biofilm production. Furthermore, an antimicrobial susceptibility test was conducted using the minimal bactericidal concentration (MBC) method against the two ethanolic extracts. The toxic potential was measured through a toxicity test with Artemia salina. The quantification of the phenolic compounds revealed that the ethanolic extracts of M. tenuiflora and C. leptophloeos possessed higher amounts of myricetin (43.2 and $294.9 \mathrm{mg}$ in $10 \mathrm{~g}$, respectively) in relation to the other compounds. A $39.4 \%$ positivity rate was observed in the $n u c$ gene
\end{abstract}

\footnotetext{
${ }^{1}$ Discente do Curso de Graduação em Agronomia, Instituto Federal de Educação do Sertão Pernambucano, IF SERTÃO-PE, Petrolina, PE, Brasil. E-mail: maura.marisousa@gmail.com

2 Discente do Curso de Pós-Graduação em Ciência e Saúde Animal, Doutorado, Universidade Federal de Campina Grande, UFCG, Patos, PB, Brasil. E-mail: renatavet peixoto@hotmail.com

3 Pesquisadores, IF SERTÃO-PE, Petrolina, PE, Brasil. E-mail: rafael.liborio17@gmail.com; eliatania.costa@ifsertao-pe.edu.br

4 Discente do Curso de Pós-Graduação em Ciência Animal, Mestrado, Universidade Federal do Vale do São Francisco, UNIVASF, Petrolina, PE, Brasil. E-mail: beatriz@zootecnista.com.br

5 Profs. Drs., IF SERTÃO-PE, Petrolina, PE, Brasil. E-mail: marcos.santos@ifsertao-pe.edu.br; luciana.jatoba@ifsertao-pe.edu. br; rodolfo.peixoto@ifsertao-pe.edu.br

6 Profs. Drs., Colegiado de Zootecnia, UNIVASF, Petrolina, PE, Brasil. E-mail: mmatiuzzi@hotmail.com; gisele.veneroni@ univasf.edu.br

* Author for correspondence
} 
investigation. The biofilm production analysis revealed that $96.9 \%$ of the isolates produced biofilm, evidencing the evolution the microorganisms regarding the development of resistance mechanisms. The MBC results showed an inhibition range between 195.30 and $3125.00 \mu \mathrm{g} \mathrm{mL}^{-1}$ and between 781.20 and $6250.00 \mu \mathrm{g} \mathrm{mL} \mathrm{m}^{-1}$ for the extracts of M. tenuiflora and C. leptophloeos, respectively. The M. tenuiflora extract showed the highest activity, suppressing $100 \%$ of the bacterial isolates $(\mathrm{n}=26)$, whereas the extract of C. leptophloeos showed an inhibition percentage of $69.23 \%$. The crude ethanolic extract (EEB) of M. tenuiflora was found to be toxic, presenting a DL50 of $118.356 \mu \mathrm{g} \mathrm{mL} \mathrm{m}^{-1}$. In contrast, the EEB of C. leptophloeos was found to be non-toxic (DL50 $\left.=1527.430 \mu \mathrm{g} \mathrm{mL}^{-1}\right)$. In conclusion, both native Caatinga species presented antibacterial activity and myricetin was the major compound. These findings highlight the need for further studies regarding the identification of anti-mastitis products from natural extracts.

Key words: Antibacterial potential. Goat and sheep farming. Commiphora leptophloeos. Mastitis. Mimosa tenuiflora.

\section{Resumo}

A mastite é responsável por danos à saúde animal e prejuízos financeiros ao produtor. Na busca por alternativas eficazes no controle da mastite, destacam-se os produtos naturais extraídos de diversas plantas que possuem ação antibacteriana. Neste contexto, o presente trabalho teve por objetivo avaliar o potencial antimicrobiano in vitro do extrato etanólico de duas espécies do bioma caatinga frente a bactérias isoladas de casos de mastite subclínica em pequenos ruminantes. As folhas de jurema preta e umburana de cambão foram secas e processadas para obtenção dos extratos etanólicos bruto para o estudo da composição fenólica. Foram utilizados 33 isolados de Staphylococcus spp. provenientes da bacterioteca do Laboratório de Controle de Qualidade de Alimentos do IF SERTÃO-PE. Com os isolados de Staphylococcus spp. realizou-se a análise de quantificação da produção de biofilme. Além disso, empregou-se o teste de sensibilidade antimicrobiana, utilizando-se a técnica da concentração bactericida mínima (CBM) frente aos dois extratos etanólicos. Para conhecer o potencial tóxico, utilizou-se o teste de toxicidade com Artemia salina. A análise de quantificação dos compostos fenólicos demonstrou que os extratos etanólicos de jurema preta e umburana de cambão apresentaram a miricetina em quantidades bastante elevadas, 43,2 e $294,9 \mathrm{mg}$ em $10 \mathrm{~g}$ respectivamente, em relação aos demais compostos detectados. Na pesquisa do gene nuc, observou-se uma positividade de $39,4 \%$. A análise da produção de biofilme revelou que $96,9 \%$ dos isolados apresentaram a capacidade de produção do biofilme, evidenciando a evolução destes micro-organismos quanto ao desenvolvimento de mecanismos de resistência. Os resultados referentes à concentração bactericida mínima indicaram uma faixa de inibição entre 195,30 a 3125,00 e 781,20 a 6250,00 $\mu \mathrm{g} \mathrm{mL}^{-1}$ para os extratos de jurema preta e umburana de cambão, respectivamente. Observou-se maior atividade para o extrato de jurema preta, que inibiu $100 \%$ dos isolados bacterianos ( $\mathrm{n}=26$ ), enquanto o extrato de umburana de cambão apresentou um percentual de inibição de $69,23 \%$. Evidenciou-se a atividade tóxica do extrato etanólico bruto (EEB) de jurema preta, que apresentou uma DL50 de $118,35 \mu \mathrm{g} \mathrm{mL}^{-1}$. Por outro lado, o EEB de umburana de cambão apresentou-se como atóxico (DL50 $=1527,43 \mu \mathrm{g} \mathrm{mL}^{-1}$ ). Considerando que as duas espécies nativas da caatinga apresentaram atividade antibacteriana e que a miricetina foi o composto majoritário, tem-se a possibilidade de desenvolvimento de novas linhas de investigação, visando a obtenção produtos antimastíticos à base de extrato natural.

Palavras-chave: Atividade antibacteriana. Caprinovinocultura. Commiphora leptophloeos (Mart.) J. B. Gillett. Mastite. Mimosa tenuiflora (Willd.) Poir.

\section{Introduction}

Goat and sheep farming are an important part of the regional economy of northeastern Brazil, and are among the key activities in familial agriculture $(\mathrm{K}$. A. Ribeiro \& Alencar, 2018). This region harbors more than $90 \%$ and $60 \%$ of the national herds of 
goats and sheep, respectively (Instituto Brasileiro de Geografia e Estatística [IBGE], 2017).

Although the Northeast region contains the majority of these herds, various challenges, especially those arising due to unsanitary conditions, have hindered the expansion of animal farming activities throughout the region. For example, mastitis is a significant disease, usually caused by bacteria, characterized by the inflammation of mammary glands. In terms of etiology, in dairy goats, intramammary infections are usually caused by different species of the genus Staphylococcus (Contreras et al., 2007; Santos et al., 2019).

Mastitis causes damages to animal health and economic losses to the livestock industry (Peixoto, Mota, \& Costa, 2010a). Mastitis is commonly controlled using a variety of medicinal products, such as antibiotics. However, their constant and indiscriminate use has raised serious concerns regarding clinical safety and public health due to residues in the milk owing to noncompliance with treatment guidelines. The bacteria present in the milk are not always fully eliminated even after pasteurization. In addition, bacterial resistance may be exacerbated (Cades et al., 2017; Oliveira et al., 2019).

Some issues, such as the non-commercialization of milk produced by treated animals, high costs due to antibiotic dependence, and bacterial resistance to these compounds, have prompted researchers to attempt identification of new alternatives to treat mastitis (Loguercio et al., 2006). Pereira et al. (2015) recognized that natural products are an economic therapeutic option in the control of diseases in developing countries.

Despite the genetic diversity of Brazilian plant species, less than $10 \%$ have been biologically characterized, and less than $5 \%$ have been subjected to detailed phytochemical studies. Even with research increasing in this area, plants are an underused, yet promising, source for the discovery of new biologically active substances (Luna et al., 2005).

Therefore, in the search for effective alternatives for mastitis treatment, the potential use of a variety of plants with antibacterial activities is worth investigating. The study of phytotherapeutic species is considered to be of global importance plant-derived compounds have low toxicity toward humans and animals and are less likely to induce bacterial resistance (Oliveira et al., 2019). Therefore, this study aimed to evaluate the in vitro antimicrobial potential of the ethanolic extract of two native Caatinga species against Staphylococcus.

\section{Material and Methods}

This study was conducted in the Laboratory of Chemistry, the Laboratory of Food Quality Control and the Laboratory of Liquid Chromatography of the IF SERTÃO-PE, and the Laboratory of Microbiology and Animal Immunology of the Federal University of São Francisco Valley (UNIVASF), respectively.

\section{Collection and identification of vegetation}

The leaves of Mimosa tenuiflora (Willd.) Poir. (Jurema preta) and Commiphora leptophloeos (Mart.) J. B. Gillett (Umburana de cambão) were collected in the municipality of Petrolina-PE at the following coordinates: $09^{\circ} 20^{\prime} 14.9^{\prime \prime} \mathrm{S}, 040^{\circ} 41^{\prime} 30.3$ " $\mathrm{W}$ and $09^{\circ} 20^{\prime} 37.6^{\prime \prime} \mathrm{S}, 040^{\circ} 41^{\prime} 25.3^{\prime \prime} \mathrm{W}$, respectively. Exsiccates were prepared from the botanic material, presenting the following registration number: 5.276 for M. tenuiflora and 5.277 for C. leptophloeos.

\section{Processing of the vegetation}

The leaves were subjected to drying in a forcedair oven at a temperature of $40^{\circ} \mathrm{C}$ for three days, and then crushed in a cutting mill until a powdered material was obtained. Afterward, the preparation of the crude ethanolic extracts (EEBs) began, in which 
the powdered material was subjected to exhaustive maceration in $99.3 \%$ ethanol. Four extractions were performed at $72 \mathrm{~h}$ intervals.

\section{Analysis of phenolic compounds - HPCL-DAD}

The method employed for the determination of the phenolic compound profiles of the extracts was validated by Padilha et al. (2017), with adaptations from Dutra, Rodrigues, Oliveira, Pedreira and Lima (2018). The individual phenolic compounds were determined by HPLC-DAD (High Performance Liquid Chromatography) using an LC Agilent 1260 Infinity system (Agilent Technologies, Santa Clara - EUA), a liquid chromatograph attached to a quaternary solvent pump (model G1311C) and deaerator, a thermostatted column compartment (G1316A), an automatic sample changer (G1329B), and a photodiode array detector (DAD) (model G1315D).

The data were processed using OpenLAB CDS ChemStation Edition software (Agilent Technologies, Santa Clara - EUA). The column used was a Zorbax Eclipse Plus RP-C18 $(100 \times 4.6 \mathrm{~mm}$, $3.5 \mu \mathrm{m})$, and the pre-column was a Zorbax C18 (12.6 $\times 4.6 \mathrm{~mm}, 5 \mu \mathrm{m}$ ) (Zorbax, EUA). The temperature of the oven was $35^{\circ} \mathrm{C}$, and the injection volume of the sample solution was $20 \mu \mathrm{L}$, previously diluted in phase $\mathrm{A}\left(10 \mathrm{mg} \mathrm{mL}^{-1}\right)$ and filtered through a 0.45 $\mu \mathrm{m}$ membrane (Millipore, Barueri, SP, Brazil). The solvent flow was $0.8 \mathrm{~mL}$ per minute. The gradient used during the separation was from 0 to 5 minutes: $5 \% \mathrm{~B} ; 5$ to 14 minutes: $23 \% \mathrm{~B} ; 14$ to 30 minutes: $50 \% \mathrm{~B}$; 0 to 33 minutes: $80 \% \mathrm{~B}$, in which solvent $\mathrm{A}$ was a phosphoric acid solution $(0.1 \mathrm{M}, \mathrm{pH}=2.0)$ and solvent B was acidified methanol with $0.5 \% \mathrm{H}_{3} \mathrm{PO}_{4}$. Detection of the compounds was performed at 220 , 280, 320, 360, and $520 \mathrm{~nm}$, and identification and quantification were performed through comparison to external standards.
Genotypic identification of isolates of Staphylococcus spp.

In total, 33 bacterial isolates, phenotypically recognized as Staphylococcus spp., were used prevenient from the bacterial collection of the Laboratory of Food Quality Control of IF SERTÃOPE. The DNA of these isolates were extracted and purified according to the methodology proposed by Aldous, Pounder, Cloud and Woods (2005), with adaptations. The genotypic identification of the isolates of Staphylococcus spp. was performed using PCR amplification of the nuc gene (Kateete et al., 2010).

\section{Biofilm quantification}

Biofilm quantification was performed through the microplate adhesion technique (Merino et al., 2009) using Staphylococcus aureus ATCC 25923 as a positive control and sterile Tryptone Soya Broth (TSB) as a negative control.

A bacterial suspension was formed from each isolate, with turbidity equivalent to the 0.5 tube of the MacFarland standards. Afterward, inoculations were performed in $3 \mathrm{~mL}$ of the TSB broth enriched with $0.25 \%$ glucose and incubated at $37^{\circ} \mathrm{C}$ for $24 \mathrm{~h}$. Later, $195 \mu \mathrm{L}$ of TSB glucose was added to 96-well microplates along with the previously incubated bacterial solution. Once again, the microplate was subjected to incubation at $37^{\circ} \mathrm{C}$ for $24 \mathrm{~h}$, then washed three times with $200 \mu \mathrm{L}$ of sterile distilled water. Next, the wells were stained with $100 \mu \mathrm{L}$ of gentian violet $(0.25 \%)$ for $5 \mathrm{~min}$ and washed again three times with sterile distilled water. To complete the process, $200 \mu \mathrm{L}$ of alcohol-acetone (80:20) was added. The microplates were subjected to absorbance analysis through a microplate scanner (model EXPERT PLUSUV) with a wavelength of $620 \mathrm{~nm}$. The assays were held on triplicate samples, and, according to the optical density values (O.D.) obtained in the reading, the isolates were classified on the basis of biofilm production as negative, weak, moderate, or strong producers. 


\section{Antimicrobial susceptibility test}

In total, 25 isolates, eight $S$. aureus and 17 Staphylococcus spp., were used for the susceptibility test with the plant extracts. The Methicillinsensitive $S$. aureus (MSSA) strain, lineage ATCC 25923 reference strain from the American Type Culture Collection, was also used in the assay, as recommended by Cos, Vlietinck, Berghe and Maes (2006).

The susceptibility tests were initiated with $0.25 \mathrm{~g}$ of each ethanolic extract diluted in $10 \mathrm{~mL}$ of the defined diluent ( $40 \%$ ethanol for the EEB of M. tenuiflora and $92.3 \%$ ethanol for the EEB of C. leptophloeos) to obtain a stock solution at a concentration of $25 \mathrm{mg} \mathrm{mL}^{-1}$. Determination of the minimal bactericidal concentration (MBC), based on the M7-A7 document (Clinical and Laboratory Standard Institute [CLSI], 2006), consisted of the distribution of $200 \mu \mathrm{L}$ of the Mueller-Hinton broth in microtitration plates. Afterward, $200 \mu \mathrm{L}$ of the stock solution of the extract was added to the first well and, after homogenization, was transferred to the second well, and so on, until the following final concentrations were obtained: $12,500,6,250,3,125$, 1,562.5, 781.2, 390.6, 195.3, and $97.6 \mu \mathrm{g} \mathrm{mL}^{-1}$. An equal proceeding was performed for the control of the diluent, in which the stock solution was replaced by the solvent, taking into consideration the smaller $\mathrm{MBC}$ than the one obtained by the diluent.

In the preparation of the inoculum, colonies obtained in Mueller-Hinton ( $\mathrm{MH}$ ) agar were used to obtain a bacterial suspension with turbidity equivalent to the 0.5 tube of the MacFarland standards, later adjusted in a spectrophotometer at $625 \mathrm{~nm}$. From this suspension, $10 \mu \mathrm{L}$ was inoculated into the wells of the microplates containing the diluted ethanolic extract. The material was incubated at $37^{\circ} \mathrm{C}$ for $24 \mathrm{~h}$ under aerobic conditions. After, the microplate content was pricked out with a sterile rechipper, cultivated in $\mathrm{MH}$ agar, and incubated for $48 \mathrm{~h}$ at $37^{\circ} \mathrm{C}$ for the determination of the $\mathrm{MBC}$ as the lowest concentration of the ethanolic extract in the study able to cause bacterial death. All assays were conducted in triplicate. The data were treated through descriptive and inferential statistical analysis, with the distribution of values in absolute and relative numbers. The MBC mean values were analyzed by the Mann-Whitney test.

\section{Toxicity test with Artemia salina}

The toxicity test was performed according to the methodology of Meyer et al. (1982), with adaptations. A saline solution was prepared (with sea salt and sterile distilled water) at a concentration of $30 \mathrm{~g} \mathrm{~L}^{-1}$. This solution was used to hatch the eggs of $A$. salina and in the preparation of the remaining dilutions. The eggs hatched in the saline solution over $24 \mathrm{~h}$ in an aquarium divided by partitions with $0.02 \mathrm{~cm}$ holes. On one side of the aquarium, 40 mg of cists of $A$. salina were added under careful observation to ensure that the cists did not trespass across the partition. This section of the aquarium was then covered with aluminum foil so that the organisms, once hatched, would be attracted by the artificial light that had been set up on the other side of the aquarium, forcing the passage of these organisms through the partition. After the eggs hatched, approximately 10 nauplii of $A$. salina were transferred with a micropipette to containers with the saline solution, and the samples were tested under different concentrations $\left(1000 \mu \mathrm{g} \mathrm{mL}^{-1}, 100 \mu \mathrm{g} \mathrm{mL} \mathrm{m}^{-1}\right.$, $10 \mu \mathrm{g} \mathrm{mL}^{-1}$, and $\left.1 \mu \mathrm{g} \mathrm{mL}^{-1}\right)$. The test was followed by a negative control. After $24 \mathrm{~h}$ of contact with the tested substances, the living and dead nauplii were counted. The tested substances were crude ethanolic extracts (EEBs) of Commiphora leptophloeos and Mimosa tenuiflora. Each tested concentration was performed in triplicate. The dose that caused a lethality of $50 \%$ of the nauplii (DL50) was obtained through calculations using the PROBIT method of analysis, with a $95 \%$ reliability rate. 


\section{Results and Discussion}

The extraction of the compounds of $M$. tenuiflora and C. leptophloeos presented yields of $14.34 \%$ and $6.3 \%$, respectively. Specific factors, including the extraction methods, solvents, temperature, and characteristics of the vegetation, are fundamental to the quality and yield of the compounds extracted from a plant. These factors considerably affect the content of the secondary metabolites extracted, thereby affecting the yield and final composition of the extracts (Karabegović et al., 2014).

In the chromatograms obtained from the ethanolic extract of $M$. tenuiflora, the main peaks corresponded to the following substances: gallic acid $(280 \mathrm{~nm})$; epigallocatechin gallate $(220 \mathrm{~nm})$; trans-resveratrol $(320 \mathrm{~nm})$, and Myricetin $(360 \mathrm{~nm})$ (Figure 1).

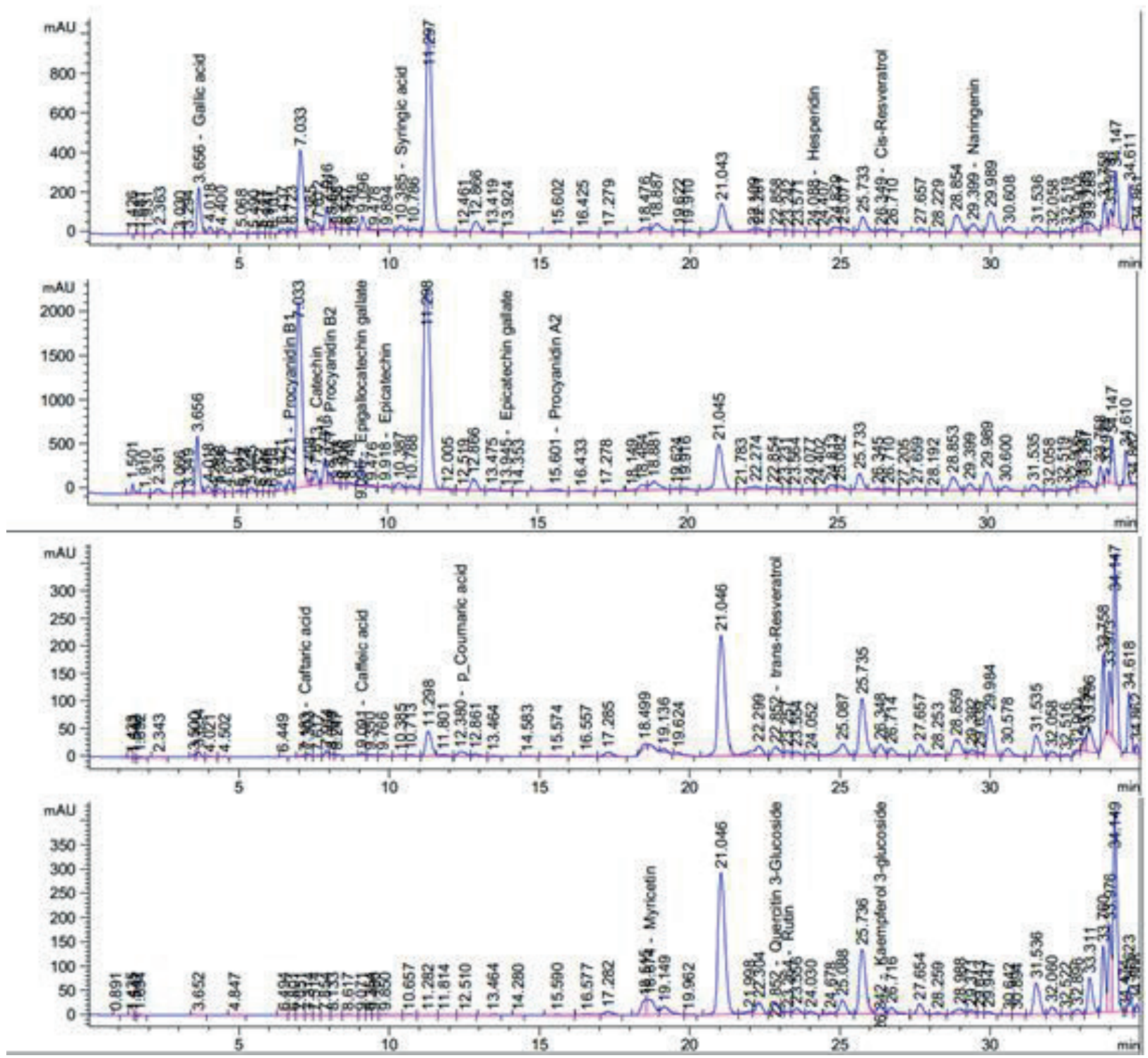

Figure 1. Chromatograms of the ethanolic extract of Mimosa tenuiflora with the detection of wavelengths of 280 , 220,320 , and $360 \mathrm{~nm}$. 
In the ethanolic extract of C. leptophloeos, (220 nm); trans-resveratrol $(320 \mathrm{~nm})$, and myricetin the main peaks corresponded to the following and quercetin3-glycoside (both $360 \mathrm{~nm}$ ) (Figure 2). substances: hesperidin $(280 \mathrm{~nm})$; epicatechin gallate

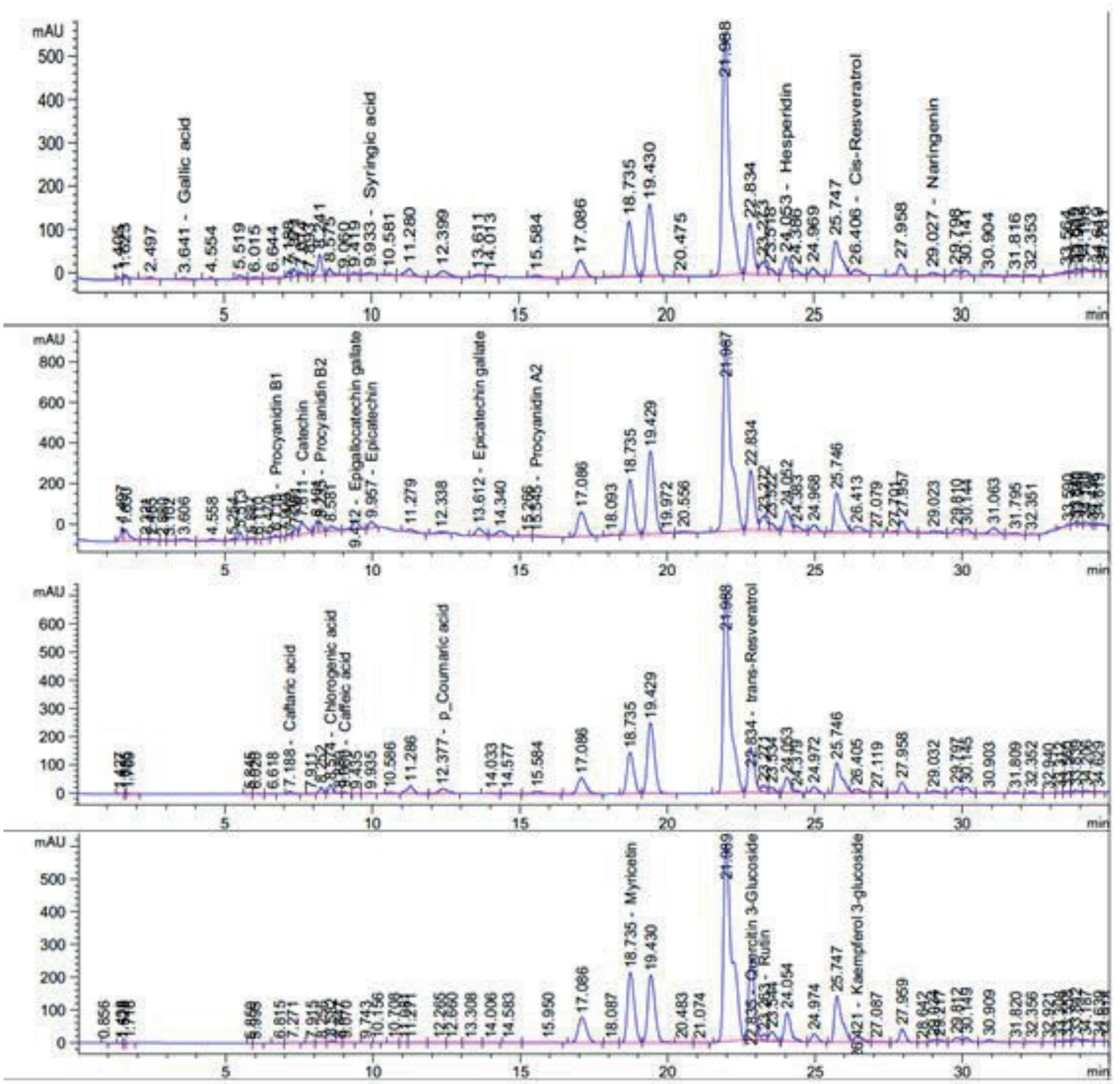

Figure 2. Chromatograms of the ethanolic extract of Commiphora leptophloeos with the detection of wavelengths of $280,220,320$, and $360 \mathrm{~nm}$.

The quantification of the phenolic compounds demonstrated that the ethanolic extracts of $M$. tenuiflora and C. leptophloeos possessed higher quantities of myricetin, 43.2 and $294.9 \mathrm{mg}$ in 10 $\mathrm{g}$, respectively, in relation to the other detected compounds (Table 1). In a study on the antibacterial activity of 38 different flavonoids against $S$. aureus, some, including myricetin, datiscetin, quercetin, luteolin, and kaempferol, showed inhibitory activity against methicillin-resistant $S$. aureus (MRSA) (Xu \& Lee, 2001). 
In the ethanolic extract of $M$. tenuiflora, the flavonol group was the most abundant $(56.5 \mathrm{mg}$ in $10 \mathrm{~g})$, followed by the phenolic acids $(39.06 \mathrm{mg}$ in

$10 \mathrm{~g})$. In the ethanolic extract of C. leptophloeos, too, the flavonol group was the most abundant (357.4 $\mathrm{mg}$ in $10 \mathrm{~g}$ ). Myricetin being the major compound in both extracts.

\section{Table 1}

Phenolic profile of the ethanolic extracts of Mimosa tenuiflora and Commiphora leptophloeos

\begin{tabular}{|c|c|c|}
\hline Phenolic compounds & $\begin{array}{l}\text { Mimosa tenuiflora } \\
(\mathrm{mg} \text { per } 10 \mathrm{~g})\end{array}$ & $\begin{array}{c}\text { Commiphora leptophloeos } \\
\text { (mg per } 10 \mathrm{~g})\end{array}$ \\
\hline \multicolumn{3}{|l|}{ Flavanols } \\
\hline Catechin & 6.9 & 2.6 \\
\hline Epicatechin & 0.71 & 0.73 \\
\hline Epicatechin gallate & 0.9 & 4 \\
\hline Epigallocatechin gallate & 18 & 2.3 \\
\hline Procyanidin A2 & 3 & 0.64 \\
\hline Procyanidin B1 & 3 & 0.32 \\
\hline Procyanidin B2 & 6.7 & 2.6 \\
\hline$\sum$ Flavanols & 38.6 & 13.19 \\
\hline \multicolumn{3}{|l|}{ Flavonols } \\
\hline Quercetin 3-glucoside & 5.1 & 52.1 \\
\hline Rutin & 1 & 3.4 \\
\hline Kaempferol 3-O-Glycoside & 7.2 & 7 \\
\hline Myricetin & 43.2 & 294.9 \\
\hline$\sum$ Flavonols & 56.5 & 357.4 \\
\hline \multicolumn{3}{|l|}{ Flavanones } \\
\hline Hesperidin & 1.6 & 18.8 \\
\hline Naringenin & 7.9 & 1.3 \\
\hline EFlavanones & 9.5 & 20.1 \\
\hline \multicolumn{3}{|l|}{ Phenolic acids } \\
\hline Gallic acid & 36.2 & 0.34 \\
\hline Syringic acid & 1.6 & 0.28 \\
\hline p-Coumaric Acid & 0.51 & 1.2 \\
\hline Caffeic Acid & 0.24 & 0.22 \\
\hline Trans-caftaric acid & 0.51 & 1.8 \\
\hline Chlorogenic Acid & ND & 3.4 \\
\hline$\sum$ Phenolic acids & 39.06 & 7.24 \\
\hline \multicolumn{3}{|l|}{ Stilbenes } \\
\hline trans-resveratrol & 0.86 & 8.7 \\
\hline cis-resveratrol & 2.6 & 2.1 \\
\hline$\sum$ stilbenes & 3.46 & 10.8 \\
\hline
\end{tabular}

$\mathrm{ND}=$ Not detected. 
The nuc gene analysis revealed a positivity rate of $39.4 \%(13 / 33)$. Therefore, these 13 isolates were identified as $S$. aureus. In a study performed in Brazil, $S$. aureus was one of the main agents involved in cases of mastitis in goats (Peixoto, França, Souza, Veschi, \& Costa, 2010b).

The biofilm analysis revealed that the majority of the isolates $(96.9 \%)$ had the potential for biofilm production, with 19 weak, eight moderate, and five strong producers; only one isolate did not produce biofilm (Table 2). This result represents the evolution of the microorganisms with regards to the development of resistance mechanisms. According to Dibbern, Botaro, Viziack, Silva and Santos
(2015), the majority of mastitis cases are caused by bacteria, especially $S$. aureus, a microorganism capable of producing biofilm. Scherr, Heim, Morrison and Kielian (2014) define biofilm as a group of cells attached to a biotic or abiotic surface imbedded in a protective extracellular matrix, thus granting resistance to antimicrobial drugs used during the treatment of illness, as well as to disinfectants and the immune system of the host, allowing the infection to acquire a chronic nature (Arciola, Campoccia, Speziale, Montanaro, \& Costerton, 2012; Guimarães et al., 2012; Tremblay, Caron, Blondeau, Messier, \& Jacques, 2014).

Table 2

Number of isolates of Staphylococcus spp. and their classifications according to biofilm production

\begin{tabular}{ccc}
\hline Classification & $\mathrm{N}^{\text {o }}$ of Isolates & Percentage (\%) \\
\hline Weak Production & 19 & 57.6 \\
Moderate Production & 8 & 24.2 \\
Strong Production & 5 & 15.2 \\
No Production & 1 & 3.0 \\
Total & 33 & 100.00 \\
\hline
\end{tabular}

The plants used in popular medicine are now being more thoroughly studied as potential sources of substances with activity against microorganisms that are pathogenic to humans (Mendes et al., 2011), agricultural plants, and livestock (Corrêa \& Salgado, 2011). This is because the secondary metabolites found in plants have primary roles in defense against herbivores and microorganisms, protection against ultraviolet rays, attracting pollinators and seed dispersion animals, and the production of allelopathic substances (Simões, Schenkel, Gosmann, Melo, Mentz, \& Petrovick, 2010).

With regards to the sensibility tests of the bacterial strains for the ethanolic extracts, the MBC analysis revealed an inhibition range from 195.30 to $3125.00 \mu \mathrm{g} \mathrm{mL}^{-1}$ and from 781.20 to 6250.00 $\mu \mathrm{g} \mathrm{mL} \mathrm{m}^{-1}$ for M. tenuiflora and C. leptophloeos, respectively (Table 3). 
Table 3

The susceptibility of isolates of Staphylococcus spp. to the ethanolic extracts of Mimosa tenuiflora and Commiphora leptophloeos

\begin{tabular}{lccc}
\hline \multirow{2}{*}{ Species } & \multirow{2}{*}{ Observed activity (\%) } & \multicolumn{2}{c}{ Minimal Bactericidal Concentration } \\
\cline { 3 - 4 } & & Range & Mean $\left(\mu \mathrm{gL}^{-1}\right)$ \\
\hline Mimosa tenuiflora & $100(26 / 26)$ & $195.3-3,125$ & $1,682.68^{\mathrm{a}}$ \\
Commiphora leptophloeos & $69.23(18 / 26)$ & $781.2-6,250$ & $2,734.37^{\mathrm{a}}$ \\
\hline
\end{tabular}

Means followed by the same letter are not statistically significantly different $(\mathrm{p}>0.05)$.

The extract of M. tenuiflora showed high antimicrobial activity, inhibiting 100\% of the bacterial isolates $(\mathrm{n}=26)$, including $S$. aureus ATCC 25923. According to Pereira et al. (2015), tannic solutions isolated from M. tenuiflora showed in vitro antibacterial activity against lineages of $S$. aureus and warrant more detailed studies relating to their potential therapeutic use.

Studies relating to the antimicrobial activity of $C$. leptophloeos are scarce. The ethanolic extract of this plant presented an inhibition percentage of $69.23 \%$. According to Ribeiro et al. (2014), regarding the therapeutic potential and use of medicinal plants in the Caatinga biome, C. leptophloeos presents itself as highly suitable for the treatment of several diseases, including inflammation.
In this study, it was verified that there was no significant difference between the MBC means, thus demonstrating the therapeutic potential of both studied species. This finding highlights the need for further studies relating to the antimicrobial activity of both plants and their attributes for the development of new investigation lines.

The toxicity evaluation of the ethanolic extracts in A. salina followed the classification established by Meyer et al. (1982), in which samples that showed DL50 > $1000 \mu \mathrm{g} \mathrm{mL}^{-1}$ are considered nontoxic, and samples that showed DL50 < $1000 \mu \mathrm{g}$ $\mathrm{mL}^{-1}$ are considered toxic against microcrustaceans (Table 4).

Table 4

Toxicity evaluation in Artemia salina (DL50) of the ethanolic extracts of Mimosa tenuiflora and Commiphora leptophloeos and their respective limits of the confidence interval at $95 \%$

\begin{tabular}{lccc}
\hline \multirow{2}{*}{ Samples } & \multirow{2}{*}{ DL50 $\left(\boldsymbol{\mu g} \mathbf{~ m L}^{-1}\right)$} & \multicolumn{2}{c}{ Confidence interval 95\% } \\
\cline { 3 - 4 } & & Inferior limit & Upper limit \\
\hline EEB Mimosa tenuiflora & 1527.430 & 60.110 & 38812.798 \\
EEB Commiphora leptophloeos & 118.356 & 20.042 & 698.952 \\
\hline
\end{tabular}

The toxic activity of the ethanolic extract of M. tenuiflora was demonstrated by a DL50 of $118.35 \mu \mathrm{g} \mathrm{mL}^{-1}$, which lower than the reference value. Bezerra and Falcão-Silva (2019) performed an assessment of the plants reported as toxic to ruminants in the semiarid northeast of Brazil, and the interviewees mentioned cases of intoxication of goats and pregnant sheep caused by the ingestion of the leaves of M. tenuiflora. They also reported that these intoxications played a role in congenital malformations during embryonic development, leading to serious issues for future reproduction in small ruminants. 
In contrast, the extract of $C$. leptophloeos was non-toxic $\left(\mathrm{DL} 50=1527.430 \mu \mathrm{g} \mathrm{mL}^{-1}\right)$, revealing its potential for use in the production of plant-based treatments. However, the bioassay with the nauplii of $A$. salina is only considered a screening test, and further tests are recommended for the verification of the toxic potential of potential therapeutics.

Tests with A. salina suggest its high potential for the study of biological activities, with the importance of this bioassay being established in the targeting of future phytochemical studies searching for bioactive substances (Amarante, Müller, Póvoa, \& Dolabela, 2011).

\section{Conclusions}

Both tested species presented biological activity against Staphylococcus spp. and myricetin was the main compound in the extracts. Further studies should investigate other properties of these extracts, such as toxicity, with the aim of controlling pathogens without causing unwanted effects to the host. In addition, studies for the production of plant-based therapeutics to establish a therapeutic modalities with improved efficacy should be undertaken.

\section{Acknowledgments}

We would like to thank CNPq for granting a scholarship, and IF SERTÃO-PE and UNIVASF for their support during laboratory analysis.

\section{References}

Aldous, W. K., Pounder, J. I., Cloud, J. L., \& Woods, G. L. (2005). Comparison of six methods of extracting Mycobacterium tuberculosis DNA from processed sputum for testing by quantitative Real-Time PCR. Journal Clinical Microbiology, 43(5), 2471-2473. doi: 10.1128/JCM.43.5.2471-2473.2005

Amarante, C. B., Müller, A. H., Póvoa, M. M., \& Dolabela, M. F. (2011). Estudo fitoquímico biomonitorado pelos ensaios de toxicidade frente a Artemia salina e de atividade antiplasmódica do caule de aninga (Montrichardia linifera). Acta Amazonica, 41(3), 431-434. doi: 10.1590/S0044-59672011000300015
Arciola, C. R., Campoccia, D., Speziale, P., Montanaro, L., \& Costerton, J. W. (2012). Biofilm formation in Staphylococcus implant infections. A review of molecular mechanisms and implications for biofilmresistant materials. Biomaterials, 33(26), 5967-5982. doi: 10.1016/j.biomaterials.2012.05.031

Bezerra, J. J. L., \& Falcão-Silva, V. S. (2019). Plantas relatadas como tóxicas para ruminantes no semiárido nordestino. Revista de Ciências Agroveterinárias, 18(2). doi: 10.5965/223811711812019202

Cades, M., Zanini, D. S., Souza, H. L., Silva, J. D., Fink, A. A. B., \& Muniz, I. M. (2017). Perfil de resistência antimicrobiana de mastite bovina em propriedade leiteira no município de Monte Negro/RO. Revista Brasileira de Ciências da Amazônia, 6(1), 1-62. Recuperado de http://www.periodicos. unir.br/index. php/rolimdemoura/article/view/1940/2068

Clinical and Laboratory Standard Institute (2006). Methods for dilution antimicrobial susceptibility tests for bacteria that grow aerobically: approved standards. Document CLSI M7-A7, CLSI, Wayne, Pennsylvania.

Contreras, A., Sierra, D., Sánchez, A., Corrales, J. C., Marco, J. C., Paape, M. J., \& Gonzalo, C. (2007). Mastitis in small ruminants. Small Ruminant Reserch, 68(1-2), 145-153. doi: 10.1016/j.smallrumres. 2006.09.011

Corrêa, J. C. R., \& Salgado, H. R. N. (2011). Atividade inseticida das plantas e aplicações: revisão. Revista Brasileira de Plantas Medicinais, 13(4), 500-506. doi: 10.1590/S1516-05722011000400016

Cos, P., Vlietinck, A. J., Berghe, D. V., \& Maes, L. (2006). Anti-infective potential of natural products: How to develop a stronger in vitro 'proof-of-concept'. Journal of ethnopharmacology, 106(3), 290-302. doi: 10.1016/j.jep.2006.04.003

Dibbern, A. G., Botaro, B. G., Viziack, M. P., Silva, L. F. P., \& Santos, M. V. (2015). Evaluation of methods of DNA extraction from Staphylococcus aureus in milk for use in real-time PCR. Genetics and Molecular Research, 14(1), 227-233. doi: 10.4238/2015. January. 16.6

Dutra, M. C. P., Rodrigues, L. L., Oliveira, D., Pereira, G. E., \& Lima, M. S. (2018). Integrated analyses of phenolic compounds and minerals of Brazilian organic and conventional grape juices and wines: Validation of a method for determination of $\mathrm{Cu}, \mathrm{Fe}$ and Mn. Food Chemistry, 269(2018), 157-165. doi: 10.1016/j.foodchem.2018.07.014 
Guimarães, G., França, C. A., Krug, F. S., Peixoto, R. M., Krewer, C. C., Lazzari, A. M., \& Costa, M. M. (2012). Caracterização fenotípica, produção de biofilme e resistência aos antimicrobianos em isolados de Staphylococcus spp. obtidos de casos de mastite em bovinos e bubalinos. Pesquisa Veterinária Brasileira, 32(12), 1219-1224. doi: 10.1590/S0100$736 \times 2012001200002$

Instituto Brasileiro de Geografia e Estatística (2017). Sistema IBGE de recuperação automática - SIDRA. Recuperado de http://www.sidra.ibge.gov.br

Karabegović, I. T., Stojicevic, S. S., Velickovic, D. T., Todorovic, Z. B., Nikolic, N. C., \& Lazic, M. L. (2014). The effect of different extraction techniques on the composition and antioxidant activity of cherry laurel (Prunus laurocerasus) leaf and fruit extracts. Industrial Crops and Products, 54(2014), 142-148. doi: 10.1016/j.indcrop.2013.12.047

Kateete, D. P., Kimani, C. N., Katabazi, F. A., Okenga, A., Okeel, M., Nanteza, A.,... Najjuka, F. C. (2010). Identification of Staphylococcus aureus: DNase and mannitol salt agar improve the efficiency of the tube coagulase test. Annals of Clinical Microbiology and Antimicrobials, 9(23), 1-7. doi: 10.1186/1476-07119-23

Loguercio, A. P., Groff, A. C. M., Pedrozzo, A. F., Witt, N. M., Silva, M. S., \& Vargas, A. C. (2006). Atividade in vitro do extrato de própolis contra agentes bacterianos da mastite bovina. Pesquisa Agropecuária Brasileira, 41(2), 347-349. doi: 10.1590/S0100-204X2006000200021

Luna, J. S., Santos, A. F., Lima, M. R. F., Omena, M. C., Mendonça, F. A. C., Bieber, L. W., \& Sant'Ana, A. E. G. (2005). A study of the larvicidal and molluscicidal activities of some medicinal plants from northeast Brazil. Journal of Ethnopharmacology, 97(2), 199206. doi: 10.1016/j.jep.2004.10.004

Mendes, L. P. M., Maciel, K. M., Vieira, A. B. R., Mendonça, L. C. V., Silva, R. M. F., Rolim, P. J., Neto,... Vieira, J. M. S. (2011). Atividade Antimicrobiana de Extratos Etanólicos de Peperomia pellucida e Portulaca pilosa. Revista de Ciências Farmacêuticas Básica e Aplicada, 32(1), 121-125. Recuperado de https://pdfs.semanticscholar.org/679 b/6d966a1af4b446678527c4397a952f0f6d53.pdf

Merino, N., Arana, A. T., Irigaray, M. V., Valle, J., Solano, C., Calvo, E.,... Lasa, I. (2009). Protein A-mediated multicellular behavior in Staphylococcus aureus. Journal of Bacteriology, 191(3), 832-843. doi: 10.1128/JB.01222-08
Meyer, B. N., Ferrigni, N. R., Putnan, J. E., Jacobsen, L. B., Nichols, D. E., \& McLaughlin, J. (1982). Brine shrimp: a convenient general bioassay for active plant constituents. Journal of Medical Plant Research, 45(1), 31-34. doi: 10.1055/s-2007-971236

Oliveira, S. C. C., Nishi, L., Mantovani, D., Mateus, G. A. P., Santos, T. R. T., Baptist, A. T. A.,... Bergamasco, R. (2019). Extratos de plantas brasileiras no controle da bactéria Staphylococcus aureus causadora da mastite contagiosa em bovinos leiteiros. Revista Tecnológica, 27(1), 48-58. doi: 10.4025/ revtecnol. v27i1.43745

Padilha, C. V. S., Miskinis, G. A., Souza, M. E. A. O., Pereira, G. E., Oliveira, D., Bordignon-Luiz, M. T., \& Lima, M. S. (2017). Rapid determination of flavonoids and phenolic acids in grape juices and wines by RP-HPLC/DAD: method validation and characterization of commercial products of the new Brazilian varieties of grape. Food Chemistry, 228(2017), 106-115. doi: 10.1016/j. foodchem.2017.01.137

Peixoto, R. M., França, C. A., Souza, A. F., Jr., Veschi, J. L. A., \& Costa, M. M. (2010b). Etiologia e perfil de sensibilidade antimicrobiana dos isolados bacterianos da mastite em pequenos ruminantes e concordância de técnicas empregadas no diagnóstico. Pesquisa Veterinária Brasileira, 30(9), 734-740. doi: 10.1590/ S0100-736X2010000900005

Peixoto, R. M., Mota, R. A., \& Costa, M. M. (2010a). Mastite em pequenos ruminantes no Brasil. Pesquisa Veterinária Brasileira, 30(9), 754-762. doi: 10.1590/ S0100-736X2010000900008

Pereira, A. V., Azevedo, T. K. B., Santana, G. M., Trevisan, L. F. A., Higino, S. S. S., Costa, R. M.,... Azevedo, S. S. (2015). Análise da atividade antimicrobiana de taninos totais de plantas aromáticas do Nordeste brasileiro. Revista Agropecuária Técnica, 36(1), 109-114. doi: 10.25066/agrotec.v36i1.23009

Ribeiro, D. A., Macêdo, D. G., Oliveira, L. G. S., Saraiva, M. E., Oliveira, S. F., Souza, M. M. A., \& Menezes, I. R. A. (2014). Potencial terapêutico e uso de plantas medicinais em uma área de Caatinga no estado do Ceará, nordeste do Brasil. Revista Brasileira de Plantas Medicinais, 16(4), 912-930. doi: 10. 1590/1983-084X/13_059

Ribeiro, K. A., \& Alencar, C. M. M. (2018). Desenvolvimento territorial e a cadeia produtiva da caprinovinocultura no semiárido baiano: o caso do município de Juazeiro-BA. Revista Brasileira de Assuntos Regionais e Urbanos, 4(1), 144-179. doi: 10.18224/baru.v4i1.6571 
Santos, D. A., Jr., Matos, R. A. T., Melo, D. B., Garino, F., Jr., Simões, S. V. D., \& Miranda, E. G. (2019). Etiologia e sensibilidade antimicrobiana in vitro de bactérias isoladas de cabras com mastite no Sertão e Cariri paraibano. Ciência Animal Brasileira, 20, 1-11. doi: 10.1590/1089-6891v20e-44848

Scherr, T. D., Heim, C. E., Morrison, J. M., \& Kielian, T. (2014). Hiding in plain sight: Interplay between staphylococcal biofilms and host immunity. Frontiers in Immunology, 5(37), 1-7. doi: 10.3389/ fimmu. 2014.00037

Simões, C. M. O., Schenkel, E. P., Gosmann, G., Melo, J. C. P., Mentz, L. A., \& Petrovick, P. R. (2010). Farmacognosia: da planta ao medicamento. Florianópolis, SC: UFSC.
Tremblay, Y. D., Caron, V., Blondeau, A., Messier, S., \& Jacques, M. (2014). Biofilm formation by coagulasenegative staphylococci: Impact on the efficacy of antimicrobials and disinfectants commonly used on dairy farms. Veterinary Microbiology, 172(3-4), 511518. doi: 10.1016/j.vetmic.2014.06.007

Xu, H. X., \& Lee, S. F. (2001). Activity of plant flavonoids against antibiotic - resistant bacteria. Phytotherapy Research, 15, 39-43. doi: 10.1002/1099-1573(200102)15:1<39::AIDPTR684>3.0.CO;2-R 
